\title{
The Present Specification and Acceptance Program for Dental Materials and Devices in Japan
}

\author{
by
}

Masayoshi OHASHI*

\section{A Brief History of Specification Program for Dental Materials and Devices.}

The first step in the direction of specification for dental materials in Japan was made in 1931, when the Japan Society for Dental Materials was established and the initial draft was prepared. After careful discussions, specifications were adopted in order and we had 14 specifications in 1938. Later on, 8 more specifications were added and this brought up the total number to be 22 in 1943, as given in Table 1. However, the Society came to be disorganized in this year because of the Pacific War. These specifications served as useful guidelines for the manufacture of dental materials both during and after the war.

The present industrial standardization in Japan has been carried forward in conformity with the Industrial Standardization Law established and put into force in 1949. The purpose of the Law is to promote industrial standardization by setting up proper and rational industrial standards and spreading their general utilization. The Law is broadly composed of a system to establish the Japanese Industrial Standards (known as JIS) which constitutes the basis of industrial standardization and the JIS Marking System for the furtherance and popularization of JIS. JIS are established by the relevant ministers in conformity with the Law. Specifications for dental materials and devices are included in JIS and come under the jurisdiction of the Minister of Public Welfare in Japan.

\section{An Outline of JIS}

JIS are classified into 17 sections, as given in Table 2. Medical and dental materials and devices come under the Medical Instruments and Appliances Section with a code of T. This section code and 4 digits constitute the notation of the JIS number. For instance, as given in Fig. 1, JIS for dental amalgam alloy is expressed by the

*大橋正敬, Dept. of Dental Materials, Nihon University School of Dentistry, Tokyo and Vice Chairman of the Commission on Dental Materials, Instruments, Equipment and Therapeutics, Fédération Dentaire Internationale.

Parts of the paper were read before the Open Session entitled "The Specification, Certification and Utilization of Dental Materials" of the Commission on Dental Materials, Instruments, Equipment and Therapeutics, the 61st Annual Session of the Fédération Dentaire Internationale, Sydney, Australia, Tuesday, July 17, 1973. 
notation of JIS T 6109 , where T is the section code, 61 is classification No. and 09 is an individual No.

Table 1 Specification of the Japan Society for Dental Materials (1943).

\begin{aligned} \hline Spec. No. & Title \\ \hline 1 & Silver-Amalgam Alloy \\ 2 & Mercury for Dental Amalgam \\ 3 & Fusible Alloy \\ 4 & Non-Casting Alloy \\ 6 & Casting Alloy \\ 7 & Solder \\ 8 & Non-Casting Gold Alloy \\ 9 & Casting Gold Alloy. \\ 10 & Non-Casting Silver-Palladium Alloy \\ 11 & Casting Silver-Palladium Alloy \\ 12 & Silver Solders \\ 13 & Non-Casting Silver Alloy as Substitute Gold Alloy \\ 14 & Casting Silver Alloy as Substitute Gold Alloy \\ 15 & Zinc Phosphate Cement \\ 16 & Silicate Cement \\ 17 & Inlay Casting Wax \\ 18 & Inlay Casting Investment \\ 19 & Impression Compound \\ 20 & Denture Rubber \\ 21 & Acrylic Denture Resin \\ 22 & Porcelain Teeth \\ \hline & \end{aligned}

Table 2 Sections of JIS.

\begin{tabular}{ll}
\hline Code & \multicolumn{1}{c}{ JIS Section } \\
\hline A & Civil Engineering \& Architecture \\
B & Mechanical Engineering \\
C & Electrical Engineering \\
D & Automotive Engineering \\
E & Railway Engineering \\
F & Shipbuilding \\
G & Ferrous Materials \& Metallurgy \\
H & Non-Ferrous Metals \& Metallurgy \\
K & Chemical Industry \\
L & Textile Industry \\
M & Mining \\
P & Pulp \& Paper Industry \\
R & Ceramics \\
S & Domestic Wares \\
T & Medical Instruments \& Appliances \\
Z & Aircraft Industry \\
& Packaging, Welding, Fundamental, \\
\hline
\end{tabular}


Fig. 1 The Notation of Specification Number for JIS.

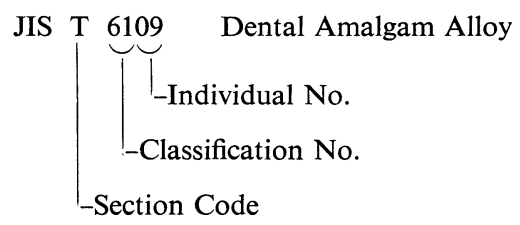

Organizations for industrial standardization work in Japan are shown in Fig. 2. JIS are developed through deliberation by the Japanese Industrial Standards Committee (known as JISC) which is set up as a consultative body to the relevant ministers and they are established by the ministers. The Japanese Industrial Standards Committee is principally composed of the Standards Council, 29 Divisional Councils and about 1,800 Technical Committees.

The Standards Council conducts the general meeting and planning with regards to the general operation of the Committee.

A Divisional Council is concerned with the establishment and abolition of Technical Committees and also reconsiders the conclusions brought forward by the Technical Committee from the standpoint of the entire industrial field concerned as supervising machinery and gives the conclusions.

Fig. 2 Organizations for Industrial Standardization Work in Japan.

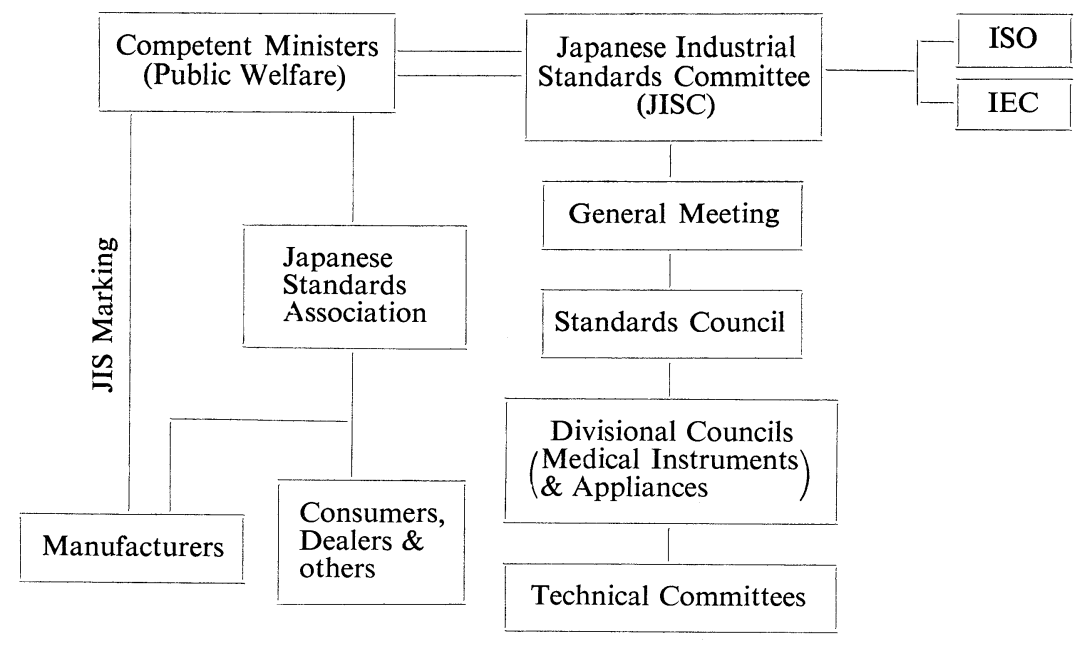

A Technical Committee is set up for a given technological problem and is formed by the manufacturers, consumers, sales people and those of neutral interest chosen on an equal basis. It is this Technical Committee that is actually involved in the deliberations required to set up individual standards.

So that each of the established JIS may always contain appropriate subjects in 
accordance with the technical progress and economic situation, they are reconsidered by the same procedures once every three years at least, so as to determine whether they should be allowed to exist in the future in the form they have existed so far, should be revised or should be abolished.

\section{JIS for Dental Materials and Devices.}

We have at present a total of 62 specification for dental materials and devices, 30 for dental materials (Table 3) and 32 for dental instruments and appliances (Table 4). These JIS do not cover all dental materials and devices used in the practice of dentistry but apply only to those materials and devices which are in high demand in Japan.

Table 3 JIS for Dental Materials.

\begin{tabular}{|c|c|}
\hline Spec. No. & Title \\
\hline (ज) $\mathrm{T} 6101$ & Nickel-Chromium Alloy Wires for Dental Use \\
\hline (ज) $\mathrm{T} 6102$ & Nickel-Chromium Alloy Plates for Dental Use \\
\hline (ज) $\mathrm{T} 6103$ & Stainless Steel Wires for Dental Use \\
\hline (5) $\mathrm{T} 6104$ & Cobalt-Chromium Alloy Wires for Dental Use \\
\hline (5) $\mathrm{T} 6105$ & Dental Wrought Gold-Silver-Palladium Alloy \\
\hline (ज) $\mathrm{T} 6106$ & Dental Casting Gold-Silver-Palladium Alloy \\
\hline (ज) $\mathrm{T} 6107$ & Gold-Silver-Palladiun Alloy Solders for Dental Use \\
\hline (ज) $\mathrm{T} 6108$ & Dental Silver Casting Alloy \\
\hline (अ) $\mathrm{T} 6109$ & Dental Amalgam Alloy \\
\hline T 6110 & Dental Fusible Alloy \\
\hline $\mathrm{T} 6111$ & Dental Silver Solders \\
\hline T 6112 & Dental Mercury \\
\hline T 6113 & Dental Casting $14 \mathrm{~K}$ Gold Alloy \\
\hline T 6114 & Plus Metals for Dental Casting $14 \mathrm{~K}$ Gold Alloy \\
\hline (5) $\mathrm{T} 6501$ & Acrylic Denture Resin \\
\hline T 6502 & Dental Paraffin Wax \\
\hline T 6503 & Dental Inlay Casting Wax \\
\hline T 6504 & Dental Impression Compound \\
\hline (ज) $\mathrm{T} 6505$ & Alginate Impression Material \\
\hline (ज) $\mathrm{T} 6506$ & Resin Teeth \\
\hline T 6507 & Temporary Stoppings for Dental Use \\
\hline $\mathrm{T} 6508$ & Dental Heat Curing Acrylic Resin for Crown \\
\hline T 6509 & Dental Self-Curing Acrylic Resin for Filling \\
\hline $\mathrm{T} 6510$ & Dental Base Plates \\
\hline $\mathrm{T} 6511$ & Porcelain Teeth for Plate Denture \\
\hline T 6601 & Dental Casting Investment \\
\hline (s) $\mathrm{T} 6602$ & Dental Zinc Phosphate Cement \\
\hline (ज) $\mathrm{T} 6603$ & Dental Silicate Cement \\
\hline (s) T 6604 & Dental Calcined Gypsum \\
\hline T 6605 & Dental Stone \\
\hline
\end{tabular}

(*) JIS Marking Products

It is true that the Gross National Products Index of Japan is high but the average income of the majority of the Japanese is still low. For this reason, substitute alloys 
such as nickel-chromium, gold-silver-palladium and silver are widely used in place of gold alloy. This means that there are JIS applicable to these substitute alloys but, on the other hand, we have no specification for dental casting gold alloy. Recently, JIS was set up for $14 \mathrm{~K}$ gold casting alloy but, because of its low gold content, it is not realistic to equate this specification with those in the other countries. These countries have their specifications for agar impression materials and zinc oxide-eugenol impression pastes but these are still lacking in Japan for the simple reason that these impression materials are not widely used. These are, it is believed, the characteristics of JIS which reflect the social conditions of Japan.

However, some of FDI specifications are adopted in JIS either in thcir original form or with only slight modifications in the JIS form.

Table 4 JIS for Dental Instruments and Appliances.

\begin{tabular}{|c|c|}
\hline Spec. No. & Title \\
\hline T 5105 & Wrist and Slip-Joint $\mathrm{K}_{4}$ for Electric Dental Engine \\
\hline T 5106 & Belts for Electric Dental Engines \\
\hline T 5107 & Stand for Electric Dental Engine \\
\hline T 5108 & Bracket Arm for Electric Dental Engine \\
\hline (ज) $\mathrm{T} 5109$ & Electric Dental Engines \\
\hline (ज) $\mathrm{T} 5201$ & Dental Bars \\
\hline T 5202 & Pulp Canal Reamers \\
\hline T 5204 & Mandrel for Dental Use \\
\hline T 5205 & Dental Pulp Canal Cleansers \\
\hline T 5206 & Dental Broaches \\
\hline T 5207 & Pulp Canal Reamers for Angle Hand-Piece \\
\hline T 5208 & Peeso's Root Reamers for Dental Use \\
\hline T 5209 & Dental Carborundum Wheels \\
\hline T 5210 & Dental Carborundum Points \\
\hline T 5401 & Dental Pincettes \\
\hline T 5402 & Dental Explorers \\
\hline T 5403 & Dental Chisel \\
\hline T 5404 & Dental Spoon Excavator \\
\hline T 5405 & Dental Plastic-Filling Instruments \\
\hline T 5406 & Dental Scalers \\
\hline T 5407 & Dental Elevators \\
\hline T 5408 & Dental Bone Files \\
\hline T 5409 & Dental Broach-Holders \\
\hline Т 5410 & Dental Forceps \\
\hline T 5411 & Dental Crown Scissors \\
\hline T 5412 & Dental Operating Knives \\
\hline Т 5413 & Dental Curettes \\
\hline T 5414 & Dental Wax Spatula \\
\hline T 5415 & Gingival Applicator \\
\hline T 5901 & Dimension for Dental Hand-Piece \\
\hline T 5902 & Dental Spitton \\
\hline T 5903 & Dental Mirror and its Holders \\
\hline
\end{tabular}

(s) JIS Marking Products 


\section{The JIS Marking System}

At present, Japan does not have anything similar to the acceptance program of American Dental Association but, instead, we have a set up for the popularization of industrial standards by the Law.

The Minister of Public Welfare has legal control over both medical and dental materials and devices in Japan, and the Minister sanctions the use of the JIS Marking for only designated products. Therefore, like other products, the medical and dental materials and devices bearing JIS Mark are indirectly guaranteed for their quality by the government. However, even if there are JIS in effect, products cannot bear a JIS Mark unless they come under the designation for JIS Marking. For this reason, it is often hard to recognize JIS-conforming products.

Referring to dental materials and devices, only 15 items of the former (Table 3) and 2 items of the latter (Table 4) are currently designated for JIS Marking. Because of importance of the materials and devices in medicine and dentistry, it is strongly felt that all items for JIS of the materials and devices in the field of medical and dental care should be designated as JIS Mark products and we should make a practical application of the JIS Marking System.

\section{Japan Dental Association and Specification Program.}

As mentioned above, although JIS are controlled by the hand of the government in Japan, opinions of the interested parties are fully reflected in establishing the specifications as realistically as possible.

The Japan Dental Association sends some delegates to the Technical Committees for JIS as representing user interest but, frankly the Association has been far from active in making up a draft for desirable specifications or expending sufficient efforts on specification programs.

Fortunately, there was quite a change in 1968. In this year, the Japan Dental Association established the Council of Dental Materials, Devices and Therapeutics and, with an idea similar to the Specification and Acceptance Program of American Dental Association, they initiated active work.

The Council, which currently forms one of major functions in the Planning and Research Division of Japan Dental Association, is engaged in drawing up drafts and other research necessary for a sound and workable specification and acceptance program to improve and insure uniform high quality of materials, devices and drugs used in clinical dentistry. In a few years, the Japan Dental Association will prepare specification drafts and complete the authoritative acceptance program alone.

\section{Future Activities for Japan.}

Since JIS is the nationally enforced system of Japan, an incorporation of such international specifications as ISO or FDI into the JIS will create no problem at all. However, an adequate application is called for in promoting effective use of them. As 
mentioned earlier, not all items for JIS of the dental materials and devices are currently designated for JIS Marking and, for this reason, we have no criteria in judging whether a given material or device which has no JIS Marking will be safe and effective for practical use. The immediate solution to this problem is to designate all the medical and dental products to the existing JIS and, the acceptance program of Japan Dental Association will doubtlessly go a long way towards bringing this realization about.

The Japanese Industrial Standards Committee take part in ISO and IEC but the number of $\mathrm{P}$ members of interested parties from Japan actively engaged in their Technical Committees is still few. For instance, as regards ISO/TC 106 Dentistry Japan participates in the capacity of an 0 member who has no right of vote. We must participate as a $\mathrm{P}$ member in ISO/TC 106 Dentistry as soon as possible, so that we will be able to cooperate more actively with various international organizations.

In terms of the number of specifications for dental materials and devices, Japan appears to be the top in the world but the mere number does not indicate the degree of spread of specifications or high standard of dental treatment maintained. It is only when specifications are operated adequately and effectively that they make valuable contributions to all those concerned.

The role of the Japan Dental Association is very important in expanding the specification and acceptance program and, at the same time, bringing about better application of the program for better dentistry for today and tomorrow. 